\title{
Dakwah Harmoni Sebagai Solusi Problem Agama dan Modernisme Perspektif Djohan Effendi
}

\author{
Muhammad Munir, Ahmad Muqaffi \\ UIN Sunan Ampel Surabaya \\ UIN Sunan Ampel Surabaya \\ muniralafasy39@gmail.com
}

\begin{abstract}
Harmony is the need of all people in this world, so in making a growing exchange and interaction between religions and a stronger tendency towards religious diversity will present a new opportunity and challenge for harmony in religious relations. As a result, exchanges between various religions occur more frequently, more opportunities are provided for religions to conduct joint learning and strengthen cooperation. In the experience of all mankind, especially in several countries and regions in the east, from various events that occur gathered a lot of experience and wisdom in terms of cultural diversity, In this study will be discussed about how the propagation of harmony exemplified by Djohan Effendy, to make this research more specifically then, in this issue we are interested in describing and identifying the thought of the propaganda of harmony Djohan Effendi. This study aims to find the propaganda of harmony in social life. This research is a library research that aims to understand and apply the propaganda exemplified by Djohan Effendi. The focus is his thoughts on the da'wah hormoni. The approach used is a historical method. This approach is used to observe and trace the process of forming ideas and thoughts of a character based on the sociocultural context of his life. The results of this study found 1) The Concept of Religious Pluralism as a Solution of Harmony Harmony According to Djohan Effendi, 2) Da'wah Harmoni Djohan Effendi.
\end{abstract}

Keywords: Da'wah Harmony; Religion; Modernism; Djohan Effendi

Abstrak. Harmoni merupakan kebutuhan semua insan yang ada di dunia ini, maka dalam melakukan suatu pertukaran dan interaksi yang berkembang di antara agamaagama dan kecenderungan yang lebih kuat terhadap keragaman agama akan menghadirkan suatu peluang dan tantangan baru bagi keharmonian dalam hubungan keagamaan. Akibatnya karena pertukaran di antara berbagai agama semakin sering terjadi, semakin banyak peluang disediakan untuk agama untuk melakukan pembelajaran bersama dan memperkuat kerja sama. Secara pengalaman seluruh umat manusia, khususnya di beberapa negara dan wilayah di timur, dari berbagai peristiwa yang terjadi terkumpul banyak pengalaman dan kebijaksanaan dalam hal keanekaragaman budaya, Dalam penelitian ini akan dibahas mengenai bagaimana dakwah harmoni yang dicontohkan oleh Djohan Effendy, untuk menjadikan penelitian ini lebih spesifik maka, dalam masalah ini kita tertarik untuk memaparkan dan mengidentifikasi pemikiran dakwah harmoni Djohan Effendi. Penelitian ini bertujuan untuk menemukan dakwah harmoni dalam kehidupan sosial, Penelitian ini merupakan penelitian pustaka (library research) yang bertujuan untuk memahami dan mengaplikasikan dakwah yang dicontohkan oleh Djohan Effendi. Fokusnya adalah pemikirannya tentang dakwah hormoni. Pendekatan yang digunakan adalah 
metode historis. Pendekatan ini digunakan untuk mengamati dan menelusuri proses terbentuknya gagasan dan pemikiran seorang tokoh berdasarkan konteks sosiokultur kehidupannya. Hasil dari penelitian ini menemukan 1) Konsep Pluralisme Agama Sebagai Solusi Umat Yang Harmoni Menurut Djohan Effendi, 2) Dakwah Harmoni Djohan Effendi.

Kata Kunci: Dakwah Harmoni; Agama; Modernisme; Djohan Effendi

\section{PENDAHULUAN}

Harmoni merupakan kebutuhan semua insan yang ada di dunia ini, maka dalam melakukan suatu pertukaran dan interaksi yang berkembang diantara agama-agama dan kecenderungan yang lebih kuat terhadap keragaman agama akan menghadirkan suatu peluang dan tantangan baru bagi keharmonian dalam hubungan keagamaan. Akibatnya karena pertukaran di antara berbagai agama semakin sering terjadi, semakin banyak peluang disediakan untuk agama untuk melakukan pembelajaran bersama dan memperkuat kerja sama. Secara pengalaman seluruh umat manusia, khususnya di beberapa negara dan wilayah di timur, dari berbagai peristiwa yang terjadi terkumpul banyak pengalaman dan kebijaksanaan dalam hal keanekaragaman budaya (Syam, 2018, h. 13).

Di lain sisi juga, tantangan seperti perselisihan agama atau bahkan konflik keagamaan sangat meningkat bahkan saat ini menjadi tren dalam lingkup keragaman agama, hal ini juga dapat mendorong pertukaran maju dan kerja sama. Di negara mayoritas penganut agama, ketidakpercayaan agama itu tumbuh hampir sebagai akibat dari kepercayaan yang tidak relevan saja menurut para penganut kepercayaan, dan akan mengakibatkan kekhawatiran kepada masyarakat bahkan akan mendatangkan konflik karena faktor agama baru yang orang-orang yakini (Natsir, 2001, h. 13).

Negara Indonesia terkenal dengan sebutan bangsa yang memiliki banyak pulau dan kaya akan budayanya. Indonesia adalah negara yang memberikan toleransi kepada warga negaranya, dan hal itu sudah terorganisir dalam sila-sila Republik Indonesia. Masyarakat Indonesia juga merupakan masyarakat yang plural, karena memiliki berbagai macam agama, suku, etnik, 
budaya dan bahasa. Meski memiliki banyak agama, tetapi masyarakatnya hidup dalam suasana toleransi, agama-agama yang diakui di Indonesia yakni Islam, Kristen, Katolik, Hindu, Budha, dan Konghucu. Dalam keragaman masyarakat Indonesia, maka untuk membangun keharmonian kepada masyarakat beda agama, khususnya masyarakat yang tidak memiliki kesamaan persepsi ini adalah tantangan untuk mewujudakan kepada masyarakat agar bisa berinteraksi sesama atau bahkan antaragama, disinilah peran harmoni itu terjadi (Nuh, 2011, h. 43).

Pesatnya teknologi memberikan kesempatan untuk mengkonstruksi masyarakat khususnya masyarakat muslim yang dianjurkan untuk melakukan ketakwaan dan kebaikan antarsesama manusia. Dalam pengaplikasian sebuah keharmonian dan toleransi pada saat ini sudah menjadi lumrah pada masyarakat jawa khususnya. Karena nilai keharmonian dan toleransi tersebut sebenarnya timbul karena adanya pejuang para walisongo yang rata-rata hidup di daerah seluruh jawa, zaman tersebut masih bernama tentang tauhid bukan kebaikan, keharmonian, sosial, toleransi, yang mana menjadikan landasan pertama pada masyarakat jawa pada saat itu (Ahmad Gaus A. F, 2009, h. 87).

Masyarakat telah menjadikan kehidupannya melalui suatu perubahan atau kita kenal dengan istilah modernisme dan menjadikan sebuah narasi sehingga menjadikan agama sebagai pemaknaan dalam kehidupan. Agama yang telah menjadikan manusia paham hal-hal tentang ilmu tauhid melalui pengetahuannya dalam kehidupan sehari-hari atau dalam pengalaman yang diperoleh dari hasil belajar, karena pada hakikatnya agama itu datang sebagai petunjuk bagi setiap orang yang kita kenal dalam islam ialah "rahmatan lil alamin" yang memberikan rahmat kepada seluruh alam yang ada di muka bumi. Dengan datangnya suatu kebudayaanlah yang mengubah esensi dan nilai keagamaan itu sendiri dengan memberikan banyak faktor kepada agama yang terjadi dalam kehidupan masyarakat saat ini. Masyarakat saat ini telah banyak menyalahartikan datangnya agama sehingga tidak membuat mereka 
rukun dengan agama atau keyakinan yang mereka yakini dan menjadikan mereka dengan hal tersebut konflik demi mempertahankan kenyakinan mereka, dari sinilah bisa kita ketahui bahwa agama memiliki relasi yang sangat kuat pada kehidupan masyarakat dan menjadikan suatu pegangan dan aturan hidup (Hardjono \& Forum Alumni MEP Australia-Indonesia, 2017, h. 76).

Fenomena agama adalah hal yang tidak bisa kita pungkiri bahwa suatu yang abadi dalam kehidupan masyarakat, dalam realita kehidupan sosial bahwa agama tidak akan terhindar dari masalah dalam kehidupan masyarakat. Relasi antara keduanya ialah karena adanya keanekaragaman budaya yang menjadikan perkembangan agama tidak tersentuh dengan hal-hal yang bersifat nyata yang dibangun oleh budaya. Perkembangan masyarakat baik dalam lingkungan, budaya, dan bahkan kehidupan sosial, akan menjadikan perkembangan pada agama itu sendiri. Proses komunikasi masyarakat baik itu dari lisan, tulisan bahkan simbol yang menjadikan pengetahuan pada agama, karena masyarakat saat ini dengan mudah bisa menyebarkan nilai-nilai keagamaan itu melalui terknologi yang kita kenal pada saat ini, dengan dampak pengaruh teknologi tersebut telah menjadikan hal-hal yang berkaitan dengan budaya telah mengikis sedikit demi sedikit bahkan menghilang. Salah satunya ialah pengetahuan spiritual yang menjadikan pondasi untuk meyakini hal yang tidak dapat kita lihat tetapi kita meyakini hal itu ada, karena hal-hal itu adalah kodrat maha kuasa yang tidak bisa kita jelaskan melalui akal sehat kita, kekuatan yang belum kita ketahui itu sangat berpengaruh dalam kehidupan masyarakat untuk selalu berpikir akan keberadaan hal yang belum pernah kita lihat (Wahid, Marijan, \& Al-Brebesy, 1999, h. 34).

Berbicara tentang Agama berarti tanpa kita sadari berbicara tentang kepercayaan baik dari kebudayaan yang memiliki relasi dan anggapan masyarakat dalam ketuhanan. Sebuah interaksi sesama manusia ialah merupakan suatu simbol dari bentuk adanya suatu keanekaragaman budaya. Makna agama setiap daerah memiliki cara sendiri untuk mengenalkan agama 
dan budaya. Kehidupan yang mengatur masyarakat ialah yang paling besar adalah agama, di dalam agama itu sendiri terdapat tatanan dan seperangkat aturan yang mengatur kehidupan bermasyarakat, hal inilah yang mereka yakini. Untuk kepercayaan tentang agama banyak dari masyarakat mempermasalahkan tentang aturan yang terdapat di dalam agama tersebut sehingga untuk menjadi toleransi itu sangat sulit dikarenakan terlalu fanatik kepada keyakinan agamanya. Hal inilah yang menjadikan penelitian ini unik yang akan menjabarkan tentang masalah agama, masyarakat modern, dan toleransi beragama. Akhir-akhir ini kita pastinya sering mendengar banyak masalah khususnya agama, masyarakat banyak menggunakan akal sehat untuk mendefinisikan agama, dan meyakini hal yang rasional saja, begitulah pola hidup masyarkat modern yang beranggapan bahwa ada keunikan dan keanehan terhadap agama yang kita yakini (Natsir, 2001, h. 98).

Dahulu agama sebagai petunjuk hidup bagi orang-orang muslim khususnya, karena adanya pergerseran dan pesatnya teknologi pada saat ini menjadikan segala sesuatu menjadikan baru, baik dari sosial, eknomi bahkan budaya yang dimodifikasi menjadi hal yang baru dan modern, karena terjadinya hal baru itu menjadikan berbagai permasalahan sosial maupun spiritual itu secara penuh berasal dari permasalahan agama, untuk itu dalam bersosial dan bermasyarakat di dalam kehidupan sehari-hari serasa nilai-nilai agama yang kita yakini mengalami pergeseran bahkan menghilang dari kehidupan masyarakat kita (Badruzaman, 2007, h. 129).

Berdasarkan fenomena yang terjadi pada masyarakat virtual atau modern, tidak semua masyarakat menghilangkan ajaran dan etika dalam agama bahkan nilai dalam sebuah kebudayaan. Sehingga tidak mempedulikan dengan moral dan sosial yang tertanam di dalam agama maupun di dalam sebuah kebudayaan. Nilai rasionalitaslah yang mereka gunakan untuk mengembangkan dan memberdayakan sebuah teknologi demi memenuhi sebuah kebutuhan agar bisa membentengi segala masalah yang terjadi. 
Perbedaan ini sangat jauh dibandingkan dengan keunikan masyarakat tradisional yang memiliki banyak ide cemerlang yang bisa menjadikan penemuan baru yang dikenal dengan sebutan modern. Masyarakat yang hidup dengan penuh kemodernan itu akan menyebabkan tidak peduli pada lingkungan sosial (Ahmad Gaus A. F, 2009, h. 54).

Penomena yang terjadi pada masyarakat tradisional yang mungkin belum bisa hidup dalam sebuah realita sosial yang terjadi saat ini yang banyak menggunakan alat dan teknologi, karena hal tersebut adalah paksaan budaya saat ini dan mau tidak mau kita harus ikut, apabila kita menentang kita akan selalu ada dibawah dan sulit untuk menyatu dengan kelompok sosial saat ini, secara pemikiran mereka itu lebih rasional tetapi tidak dicampuri dengan pekembangan dan kemajuan saat ini. Uniknya mereka memiliki cara sendiri untuk menembus sebuah modernisasi secara praktis, masyarakat tradisional hanya belum membentuk bagaimana mereka menyikapi modernisasi walaupun secara realitas mereka memiliki tahapan-tahapan agar memahami sistem modernisasi. Kehidupan masyarakat modern harus memiliki beberapa peran untuk menjadikan agama seimbang dari berbagai aspek kehidupan agar segala cara dalam kehidupan harus dimasukan kedalam realitas dan akal sehat (Roqib \& Abdul Wachid B. S, 2007, h. 76).

Fungsi dan peran keagamaan dalam kehidupan masyarakat ialah memberikan sebuah sistem dan aturan-aturan. Aturan itu sendiri mengatur sebuah sikap dan moral yang sudah diatur dalam agama dan direalitakan terhadap kehidupan sosial demi meyakini agama yang diikuti dan dipahami. Peran agamapun sangatlah penting terhadap keberlangsungan hidup masyarakat, oleh karena itu masyarakat sangatlah bergantung pada agama. Relasi agama dan masyarakatpun sangat erat sehingga menjadikan keduanya hal yang sangat penting. Dalam sebuah kepercayaan yang masyarakat anut baik karena lingkungan ataupun karena masyarakat itu sendiri, oleh karena itu fungsi agama ialah sebagai petunjuk dalam kehidupan yang menjadikan 
sebuah referensi untuk mengatur dalam kehidupan masyarakat (Wahid, 2002, h. 87).

Kemunculan agama sesungguhnya memberikan dampak positif kepada masyarakat. Terkait agama itu bukanlah masalah simbol individu melainkan sebuah keterikatan dalam bermasyarakat. Secara realitaspun agama menjadikan sebuah dorongan untuk memberikan action kepada masyarkat sehingga menghasilkan sebuah ritual dan acara-acara keagamaan lainnya yang terjadi karena adanya budaya dalam agama tersebut, hal ini bisa dikaitkan karena kebiasaan masyarakat yang positif itulah yang menjadikan peran agama itu muncul menjadikan peran agama itu muncul (Sarman, 2006, h. 143).

Hakikat agama itu sendiri sebenarnya menjadikan titik tolak yang muncul ketidakserasian antara agama dan masyarakat modern. Dari ketidakkeserasian tersebut banyak masyarakat modern salah pengertian dalam permasalahan agama, karena norma yang di terapkan dan diajarkan dalam agama. Maka dengan itu harus ada peran penting dari seorang da’i untuk mendakwahi masyarakat dengan materi agama yang benar sehingga masyarakat lebih toleran, netral, rukun dan harmoni dalam menyikapi masalah keagamaan (Asry, 2012, h. 45).

Toleransi adalah hal yang sangat dibutuhkan oleh semua insan yang ada di dunia ini, maka dalam melakukan suatu pertukaran dan interaksi yang berkembang di antara agama-agama dan kecenderungan yang lebih kuat terhadap keragaman agama akan menghadirkan suatu peluang dan tantangan baru bagi toleransi dalam hubungan keagamaan. Akibatnya karena pertukaran di antara berbagai agama semakin sering terjadi, semakin banyak peluang disediakan untuk agama untuk melakukan pembelajaran bersama dan memperkuat kerja sama. Secara pengalaman seluruh umat manusia, khususnya di beberapa negara dan wilayah di timur, dari berbagai peristiwa yang terjadi terkumpul banyak pengalaman dan kebijaksanaan dalam hal 
keanekaragaman budaya. Di lain sisi juga, tantangan seperti perselisihan agama atau bahkan konflik keagamaan sangat meningkat bahkan saat ini menjadi tren dalam lingkup keragaman agama, hal ini juga dapat mendorong pertukaran maju dan kerja sama. Di negara mayoritas penganut agama, ketidakpercayaan agama itu tumbuh hampir sebagai akibat dari kepercayaan yang tidak relevan saja menurut para penganut kepercayaan, dan akan mengakibatkan kekhawatiran kepada masyarakat bahkan akan mendatangkan konflik karena faktor agama baru yang orang-orang yakini (Pluralitas agama, 2001, h. 66).

Sebagaimana kita pahami bersama bahwa agama dianggap hal pertama yang memisahkan toleransi antarumat beragama dan agama dianggap menjadi pemicu terjadi konflik internal maupun eksternal, misalnya masalah yang sangat brutal dan sehingga menjadikan masyarakat pada negara tersebut menjadi pecah dan tidak harmoni serta tidak toleransi karena terjadi sebuah kecurigaan yang salah pada agama, sehingga terjadinya permusuhan yang tidak manusiawi sehingga menjadikan sebuah konflik yang sangat panjang dan sampai saat ini saling beranggapan yang salah, sudah banyak negara yang hancur karena tidak toleransi antarsesama. Mereka lebih memilih isu yang sangat sakral tentang agama yang tidak mau diselesaikan dengan cara kemanusiaan dan kekeluargaan. Salah satu contohnya ialah perang Palestina dan Israel yang sampai sekarang masih belum damai juga, disusul lagi dengan isu yang mengatasnamakan agama seperti ISIS di Suriah dan berbagai daerah di Timur Tengah, contoh lain misalnya seperti radikalisme, terorisme, dan masih banyak hal lainnya yang menggunakan kata agama, fenomena belakangan ini juga terjadi konflik Rohingya di Myanmar, serta Uighur di Cina dan masih banyak lagi terjadinya konflik yang dengan agama (Munir, 2012, h. 68).

Dalam penelitian ini akan dibahas mengenai bagaimana dakwah harmoni yang dicontohkan oleh Djohan Effendy, untuk menjadikan 
penelitian ini lebih spesifik maka, dalam masalah ini kita tertarik untuk memaparkan dan mengidentifikasi pemikiran dakwah harmoni Djohan Effendi. Penelitian ini bertujuan untuk menemukan dakwah harmoni dalam kehidupan sosial.

Penelitian ini merupakan penelitian pustaka (library research) yang bertujuan untuk memahami dan mengaplikasikan dakwah yang dicontohkan oleh Djohan Effendi. Fokusnya adalah pemikirannya tentang dakwah harmoni. Pendekatan yang digunakan adalah metode historis. Pendekatan ini digunakan untuk mengamati dan menelusuri proses terbentuknya gagasan dan pemikiran seorang tokoh berdasarkan konteks sosio-kultur kehidupannya.

\section{HASIL DAN PEMBAHASAN}

\section{Temuan Penelitian}

\section{Biografi Singkat Djohan Effendi}

Djohan Effendi lahir dari ayah yang bernama H. Mulkani dan ibunda yang bernama $\mathrm{Hj}$. Siti Hadijah, yang bertempat di kota Banjarmasin tanggal 1 Oktober tahun 1939. Jumlah saudara Djohan ialah sebanyak 4 orang terdiri dari satu orang perempuan dan tiga orang laki-laki. Sejak kecil Djohan lebih banyak diam dan tinggal bersama, $\mathrm{Hj}$. Siti Zahrah yang mana selaku nenek dari Djohan, dan pada saat itu sedang aktif mengikuti pengajian. Dalam berdakwah bil hal ternyata membuka jalan kepada para ulama' yang ada di Kalimantan Selatan. Sejak kecil Djohan hidup dengan lingkungan yang mayoritas muslim dan lingkungan para pedagang, tradisi berdagang itu juga Djohan dibimbing oleh kakeknya H. Masri dan neneknya Hj. Siti Zahrah. Dari keluarga Djohan sendiri aktif pada Serikat Islam. Sejak kecil Djohan sudah diajarkan untuk bisa membaca aksara Arab dan belajar al-Qur'an. Menginjak usia dewasanya Djohan pergi untuk memutuskan belajar mendalami al-Qur'an kepada imam terkenal pada waktu itu beliau adalah T.G.H Aseri. 
Sejak Djohan mulai pendidikannya di sekolah rakyat dengan durasi pendidikan selama 6 tahun, Djohan juga pernah bersekolah arab dengan masa pendidikan 3 tahun dan pernah bersekolah pendidikan guru agama Pertama dengan masa pendidikan 3 tahun yang bertempat di Banjarmasin Kalimantan Selatan. Setelah semua pendidikan di atas Djohan selesaikan ibunya ingin Djohan agar sekolah SMP, tetapi Djohan lebih memilih untuk melanjutkan ke PGAP durasi pendidikan selama lima tahun dengan predikat lulus terbaik, dari lulusan terbaik itu Djohan mendapatkan beasiswa yang diberikan oleh Pendidikan Hakim Islam Negeri Yogyakarta untuk melanjutkan studi dari tahun 1957 sampai dengan tahun 1960. Selama tinggal di Yogyakarta di sinilah dia memulai untuk menekuni keilmuan dalam budaya yang dikaji melalui sebuah aktivis dalam budaya. Di sinilah Djohan mulai mendapatkan banyak keilmuan dalam orientasi intelektual. Setelah Djohan menyelesaikan pendidikannya beliau langsung bekerja sebagai pegawai negeri sipil di Kantor Pengadilan Agama Amuntai, Hulu Sungai Utara, tidak terlalu jauh dari kota lahirnya.

Pada tahun 1960, Djohan tinggal di Yogyakarta untuk kuliah di IAIN Sunan Kalijaga yang sekarang menjadi UIN Sunan Kalijaga dan masuk Fakultas Syariah. Selama berada di kampus tersebut Djohan aktif di organisasi mahasiswa bagian intelektual. Dengan menekuni dibidang literasi Ahmadiyah yang terkumpul dalam Himpunan Mahasiswa Indonesia dan sering aktif pergi ke perpustakaan untuk menekuni bidang keilmuan. Aktifnya di HMI memberikan peluang kepada Djohan bisa bertemu dengan orangorang hebat seperti Ahmad Wahaib, M. Dawam Rahardjo, Mansur Hamid dan Nurcholis Madjid. Dawam Rahardjo mengusulkan agar membuat sebuah kajian terbatas kepada Mukti Ali yang waktu itu beliau menjadi dosen di IAIN Sunan Kalijaga setelah disetujui kajian ini diberi nama limited group. Sebagai anggota perdananya dalam kajian ini Djohan dan Wahib sekaligus menjadi perintis. 
Setelah pendidikannya selesai dua tahun kemudian, Djohan dipanggil untuk menghadap ke Sekretariat Jenderal Departemen Agama. Setelah sekian lama bekerja di Sekretariat Jenderal Agama, Djohan menjadi staf khusus Menteri Agama yang waktu itu menagnya adalah Mukti Ali selama satu priode. Djohan pernah ditempatkan sebagai Sekretaris Negara. Perannya dalam Sekretaris Negara mendapatkan tugas menulis pidato-pidato Soeharto.

Pada tahun 1993, mendapakan gelar dari departemen agama yang berupa sebuah penelitian utama setara dengan penelitian seperti profesor dan guru-guru besar lainnya yang ada dalam sebuah kampus. Dalam sambutannya, Djohan memaparkan pemikirannya tentang pemikiran moderat yang berisi penganut kaum moderat yang tidak mendapatkan sebuah keadilan.

\section{Dakwah Harmoni Djohan Effendi}

Bersedihnya Djohan Effendi karena dipertentangkan dengan sebuah konflik yang menimpa pada indonesia. Konflik itu terjadi pada tanah kelahirannya dan semakin semarak dan berkembang di dalam ruang lingkup yang sangat luas, salah satu contohnya ialah lingkup tersebut adalah keanekaragaman pemikiran seperti pemikiran Djohan yang percaya pada Islam sejak dewasa. Djohan marah setelah melihat beberapa oknum yang menyerang kelompok Muhammadiyah di Lombok Timur sampai Utara, yang terjadi selama 3 tahun. Fenomena konflik yang terjadi di kota Bogor pada tahun 2005, begitu juga konflik yang terjadi di Sukabumi pada tahun 2008. Banyak yang menderita luka-luka bahkan meninggal dunia. Pada bulan juli 2005 MUI memberikan angin keruh kepada semua pihak yang melakukan konflik, angin keruh itu ialah mengklaim bahwa ahmadiyah itu sesat.

Terjadinya masalah tersebut membuat Djohan gelisah dengan menuliskan sebuah esai yang di posting pada situs (GAI) Gerakan Ahmadiyah Indonesia. Berangkat dari tulisannya yang mengikuti sebuah situs A. Umar Said. Djohan mengutip sebuah kata-kata yang mempersuaf semua 
orang untuk empati yaitu sebuah kata jeritan dan penderitaan yang terjadi pada kelompok Ahmadiyah, selaku warga Indonesia yang mendapatkan diskriminasi dari masyarakat, dan terusir dari kampung halamannya untuk berteduh dan mendapatkan keamanan bagi dirinya.

Tragedi kemanusiaan ini termasuk sebuah pegiat Islam plural, Islam inklusif, dan Islam liberal yang paling berpengaruh di Indonesia, kelompok tersebut memberikan sebuah kritikan kepada negara melalui sebuah tragedi masalah tersebut tentang korban kemanusian. Sila Kemanusiaan yang menurut mereka dilanggar dan juga hak asasi manusia yang terjadi pada warga Ahmadiyah. Larangan menjalankan ibadah sesuai dengan keyakinan masingmasing sangatlah memerihkan hati seorang penganut agama dan kepercayaan apapun. Larangan seperti ini adalah sebuah pemerkosaan hati nurani yang menyebabkan derita batin yang tak terperikan.

\section{Konsep Pluralisme Agama Sebagai Solusi Umat Yang Harmoni Menurut Djohan Effendi}

Memulai menjadi inti pluralisme agama kemudian menguraikan makna pluralitas dan pluralisme yang memiliki satu jalur keterikatan timbal balik dan saling terkait. Kemajemukan adalah kebutuhan yang harus dicari dalam konteks kegiatan positif dan menuju kebaikan bersama. Pluralisme diartikan sebagai ideologi dan nilai-nilai prinsip yang memberi arah kepada bagaimana mengikuti, memahami, menerima, dan mengelola fakta yang disebut sebagai pluralitas sehingga tidak menjadi faktor negatif melainkan menjadikan faktor positif dalam kehidupan suatu masyarakat majemuk.

Dengan demikian, Pluralisme harus dilaksanakan dengan sepenuh hati dan dengan ide-ide yang mengarah pada Perdamaian. Selanjutnya, peneliti akan menjelaskan tiga ide dasar Djohan Effendi dalam Pluralisme Agama antara lain: pertama, teologi harmoni, kedua, manusia relatif dalam pandangan agama, dan ketiga, kebebasan beragama. 
Hak asasi manusia melekat dalam kebebasan, kebebasan satu manusia adalah kebebasan beragama, dengan dasar ini, pluralisme berpikir Djohan Effendi didorong untuk mempraktikkannya. Dalam kehidupan manusia, harus ada landasan yang berdaulat tanpa intervensi apapun, salah satunya adalah kebebasan beragama, kebebasan bertaubat, kebebasan mengikuti sekte atau doktrin agama dan bahkan kebebasan perspektif hak asasi manusia adalah kebebasan penuh. Karena kebebasan yang menyertai persyaratan tidak lagi kebebasan. Satu-satunya persyaratan yang dapat diterima adalah bahwa kebebasan tidak boleh melanggar kebebasan orang lain.

Salah satu alasan mereka menentang kebebasan beragama yang utuh adalah kebebasan beragama di Indonesia berdasarkan prinsip Tuhan. Justru karena negara kita didasarkan pada prinsip tentang Tuhan, maka negara berkewajiban untuk menjamin kebebasan yang diberikan kepada manusia di wilayah Republik Indonesia, menentukan kepercayaan mereka, apakah agama, kepercayaan, atau apa pun namanya. Suatu negara tidak memiliki peneliti dalam memutuskan agama mana yang akan dianut dan mana yang tidak boleh diadopsi. Hanya dengan kebebasan beragama yang utuh, keragaman yang tulus akan memberi makna bagi kehidupan manusia. Semua bentuk paksaan, halus atau menyamar, hanya akan melahirkan kemunafikan.

Toleransi terhadap perbedaan keyakinan adalah nilai dan kebajikan yang menghasilkan penerimaan dan rasa hormat terhadap keberadaan orang lain. Karena Toleransi sejati, tentu saja, tidak berhenti hanya pada pengakuan keberadaan orang lain yang memiliki keyakinan berbeda, mungkin bertentangan dengan kepercayaan yang kami anut, tetapi juga membutuhkan komitmen dan upaya untuk berjalan bersama dalam semangat kebersamaan dan kesetaraan. Bahkan lebih dari itu, kita harus menghormati dan membiarkan kebebasan orang lain untuk percaya dan merasakan iman yang mereka pilih, karena kita percaya dan menghayati iman yang kita anut. Sikap 
publik berasal dari apa yang telah diakui sebagai "aturan emas", dan inilah yang diajarkan dalam semua agama di dunia.

\section{PENUTUP}

Dari pemaparan di atas dapat disimpulkan bahwa Djohan Effendi telah memberikan pengaruh penting dalam dakwah harmoni sebagai solusi problem agama dan modernisme di Indonesia. Pentingnya agama untuk menunjukkan bahwa ajaran Islam bukanlah penghalang bagi modernisasi dan keberagaman agama yang ada di Indonesia. Dakwah harmoni telah memberikan top figur yaitu Djohan Effendi yang memberikan ide tentang dakwah harmoni. Ada beberapa catatan penting dalam pemikiran Djohan Effendi ialah; 1) Konsep pluralisme agama sebagai solusi umat yang harmoni menurut Djohan Effendi; 2) Dakwah Harmoni Djohan Effendi. Dari dua point penting inilah yang mengharuskan sebuah keharmonian dalam bersosial dan beragama.

\section{DAFTAR REFERENSI}

Ahmad Gaus A. F. (2009). Sang Pelintas Batas: Biografi Djohan Effendi, Cet Ke-1. Jakarta: Kerja sama Indonesian Conference on Religion and Peace [dengan] Penerbit Buku Kompas.

Asry, M. Y. (Ed.). (2012). Gerakan Dakwah Islam dalam Perspektif Kerukunan

Umat Beragama, Cet Ke-1. Jakarta: Kementerian Agama RI, Badan Litbang dan Diklat, Puslitbang Kehidupan Beragama.

Badruzaman, A. (2007). Teologi Kaum Tertindas: Kajian Tematik Ayat-Ayat Mustadh'afin dengan Pendekatan Keindonesiaan, Cet Ke-1. Yogyakarta: Kerjasama Pustaka Pelajar [dengan] P3M STAIN Tulungagung.

Djohan Effendi dan Warisan Islam yang Toleran-Tirto.ID.htm. (n.d.). .

Hardjono, C., \& Forum Alumni MEP Australia-Indonesia. (2017). Hidup damai di negeri multikultur: Pengalaman peserta pertukararan tokoh muda Muslim Australia-Indonesia.

Munir, M. (2012). Manajemen Dakwah, Cetakan Ke-3. Rawamangun, Jakarta: Kencana.

Natsir, M. (2001). Agama dan Negara Dalam Perspektif Islam, Cet Ke-1. Jakarta: Media Da'wah. 
Nuh, N. M. (Ed.). (2011). Dimensi-Dimensi Kebidupan Beragama: Studi Tentang Paham/Aliran Keagamaan, Dakwah, dan Kerukunan, Cet Ke-1. Jakarta: Kementerian Agama RI, Badan Litbang dan Diklat, Puslitbang Kehidupan Keagamaan.

Pluralitas agama: Kerukunan dalam Keragaman. (2001). Jakarta: Kompas Media Nusantara.

Roqib, M., \& Abdul Wachid B. S. (2007). Harmoni dalam Budaya Jawa: Dimensi Edukasi dan Keadilan Gender, Cet Ke-1. Yogyakarta: Pustaka pelajar.

Sarman, M. (2006). Mencari Kebenaran, Menuai Kecaman: Dibalik Kontroversi Perda Ramadhan (Ed. khusus Ramadhan.). Banjarmasin: kerjasama Pusat Kajian dan Pembangunan Daerah, Universitas Lambung Mangkurat (PK2PD UNLAM) dan Lembaga Kajian Keislaman dan Kemasyarakatan (LK3).

Syam, N. (2018). Menjaga Harmoni Menuai Damai: Islam, Pendidikan, dan Kebangsaan, Ed. 1. Rawamangun, Jakarta, Indonesia: Kencana.

Wahid, A. (2002). Abdurrahman Wabid Selama Era Lengser: Kumpulan Kolom dan Artikel, Cet Ke-1. Yogyakarta: LKiS Yogyakarta.

Wahid, A., Marijan, K., \& Al-Brebesy, M. M. (1999). Mengurai Hubungan Agama dan Negara. Jakarta: Grasindo. 